\title{
RAGE receptor and its soluble isoforms in diabetes mellitus complications
}

\section{O receptor RAGE e suas isoformas solúveis nas complicações do diabetes mellitus}

\author{
Mauren Isfer Anghebem Oliveira'; Emanuel Maltempi de Souza²; Fábio de Oliveira Pedrosa²; Rosângela Roginski Réa’; \\ Alexessander da Silva Couto Alves'; Geraldo Picheth'; Fabiane Gomes de Moraes Rego ${ }^{5}$
}

\begin{abstract}
Chronic hyperglycemia, which is present in all types of diabetes, increases the formation of advanced glycation end-products (AGEs). The interaction of AGEs with receptor of advanced glycation end-products (RAGE) initiates a cascade of pro-inflammatory and pro-coagulant processes that result in oxidative stress, stimulating the formation and accumulation of more AGE molecules. This cyclic process, denominated metabolic memory, may explain the persistency of diabetic vascular complications in patients with satisfactory glycemic control. The RAGE found in several cell membranes is also present in soluble isoforms (esRAGE and CRAGE), which are generated by alternative deoxyribonucleic acid splicing or by proteolytic cleavage. This review focuses on new research into these mediators as potential biomarkers for vascular complications in diabetes.
\end{abstract}

Key words: RAGE receptor; RAGE soluble isoforms; RAGE isoforms; diabetes complications.

\section{INTRODUCTION}

Diabetes mellitus (DM) is one of the most widespread chronic diseases worldwide, hence a major public health problem. The World Health Organization (WHO) estimates that $5 \%$ of total annual deaths worldwide are due to DM complications. Furthermore, the world mortality for this disease is expected to grow over $50 \%$ in the next 10 years ${ }^{(7)}$. In Brazil, according to the Ministry of Health, $9.7 \%$ of the population suffers from diabetes, and half of which is unaware of it ${ }^{(14)}$.

Even considering the advances in diagnosis, treatment and follow-up of diabetic patients, their life expectancy is still much lower in comparison with individuals from the same age group without this syndrome. DM is associated with an increase in morbidity and mortality due to the development of microvascular complications such as nephropathy, retinopathy and neuropathy as well as macrovascular complications such as cerebrovascular accident (CVA) and acute myocardial infarction (AMI). The latter is the major cause of death among diabetic patients ${ }^{(13)}$.

Constant and prolonged hyperglycemia causes the formation and accumulation of advanced glycation end-products (AGEs), which are adducts resulting from the non-enzymatic connection of a sugar such as glucose and an amino group of proteins ${ }^{(70)}$. The AGEs are involved in several biological reactions such as endocytic uptake and degradation, cytokine induction, growth factors and oxidative stress ${ }^{6}$ 28, 48).

The AGEs interact with several cellular receptors, including the receptor of advanced glycation end-products (RAGE), galectin-3, macrophage scavenger receptor A types I and II (SRA), 80K-H phosphoprotein and oligosaccharyltransferase -4 (OST-48). RAGE is the best characterized receptor ${ }^{(17)}$. AGE and RAGE binding causes endothelial dysfunction owing to the fact that it increases oxidative stress and stimulates pro-inflammatory and pro-coagulant agents. The activation of RAGE by AGEs is the main pathogenic cause of vascular complications in diabetic patients ${ }^{(47)}$.

Soluble isoforms of RAGE (sRAGE) have been detected in human and murine models. These isoforms may be formed by two processes: alternative splicing (endogenous secretory receptor for AGE [esRAGE]) or proteolytic cleavage (cRAGE) mediated by disintegrins and metalloproteinases ${ }^{(6)}$.

First submission on $04 / 10 / 12$; last submission on $04 / 10 / 12$; accepted for publication on 13/11/12; published on 20/04/13

1. Master's degree in Pharmaceutical Sciences (Clinical Analysis) by Universidade Federal do Paraná (UFPR); attending doctorate in Pharmaceutical Sciences by UFPR; professor at Escola de Saúde e Biocências and Pontifícia Universidade Católica do Paraná Medical School (PUC-PR).

2. Doctor in Biochemistry and Molecular Biology by UFPR; professor at the Biochemistry and Molecular Biology Department of UFPR.

3. Master's degree in Internal Medicine by UFPR; endocrinologist at the Endocrinology and Metabolism Service of Paraná (Serviço de Endocrinologia e Metabologia do Paraná-

SEMPR) from UFPR Clinical Hospital.

4. Doctor in Bioinformatics by Imperial College London.

5. Doctor in Biochemistry and Molecular Biology by UFPR; professor at the Medical Pathology Department of UFPR. 
Studies suggest that soluble isoforms of RAGE are not only risk predictors for vascular complications, but they are also therapeutic targets for the prevention in diabetic patients ${ }^{(59,70)}$.

Recent advances in mapping the genetic architecture ${ }^{(45)}$ of diabetes indicate the involvement of multiple mechanism in the disease etiology. The physiopathology of diabetes is complex and elusive, which promotes research in this area as well as the continuous pursuit of new biomarkers for prevention, detection and treatment of hyperglycemia complications. This investigation has the objective to review the main pathophysiological targets associated with hyperglycemia focusing on AGEs and RAGE effects. RAGE soluble forms, new and controversial biomarkers associated with diabetes complications, are highlighted.

\section{Metabolic pathways involved in DM complications}

DM is a disease characterized by chronic hyperglycemia due to the absence of insulin, deficiency of its action or both ${ }^{(1)}$. The morbidity and mortality of diabetes arise from micro and macrovascular complications associated with the pathology. DM accelerates atherogenesis and increases the risk for AMI and CVA. Furthermore, it leads to the development of microvascular complications such as retinopathy, nephropathy and neuropathy ${ }^{(1,43,76)}$. Long-term microcirculation involvement is a major factor that predisposes to endothelial lesion and large vessel involvement in diabetic patients ${ }^{(30)}$.

Multiple studies report that glucose metabolic pathways are linked with the development of endothelial dysfunction and, therefore, vascular complications, which are summarized in Figure 1. The dysfunction occurs not only due to the increase in metabolites that damage the endothelium, but also due to the reduction in endogenous protecting factors such as vascular endothelial growth factor (VEGF), platelet-derived growth factor (PDGF) and antioxidant enzymes, among others ${ }^{(31)}$.

As it may be observed in Figure 1, the excess of superoxide ( $\uparrow 02$ ) partially inhibits glycolytic enzyme glyceraldehyde-3-phosphate dehydrogenase ( $\downarrow$ GAPDH). This process diverts upstream metabolites to pathways of glucose overutilization, resulting in the flow increase of dihydroxyacetone phosphate (DHAP) to diacylglycerol (DAG), an activator of protein kinase $\mathrm{C}$ ( $\mathrm{PKC})$, and triosephosphate to methylglyoxal, the main intracellular precursor of AGE. The rise in fructose-6 phosphate to acetylglucosamine (UDP-N-AcGlu) increases protein modifications by 0 -linked $\mathrm{N}$ acetylglucosamine, as well as the glucose flow through polyol pathways, which consumes the phosphate from nicotinamide adenine dinucleotide phosphate (NADPH) and depletes reduced glutathione (GSH).

The main mechanisms involved in diabetes complications are the following:

a) increase in the activation of polyol pathways-aldose reductase enzyme reduces excess glucose to sorbitol (glucose alcohol) in several cells that do not use insulin, namely brain, retina, peripheral nerves and kidneys. Subsequently, sorbitol is oxidized to fructose by sorbitol dehydrogenase. The accumulation of intracellular sorbitol promotes osmotic unbalance and reduction of NADPH to cytosol, factors associated with diabetic retinopathy. Furthermore, the reduction of available NADPH leads to an increase in methylglyoxal and AGEs, which ultimately damage the endothelium ${ }^{(76)}$.

b) persistent activation of PKC- hyperglycemia increases the concentration of $\mathrm{DAG}$, which in turn activates $\mathrm{PKC}$, triggering: 1) higher vascular permeability caused by increase in VEGF expression

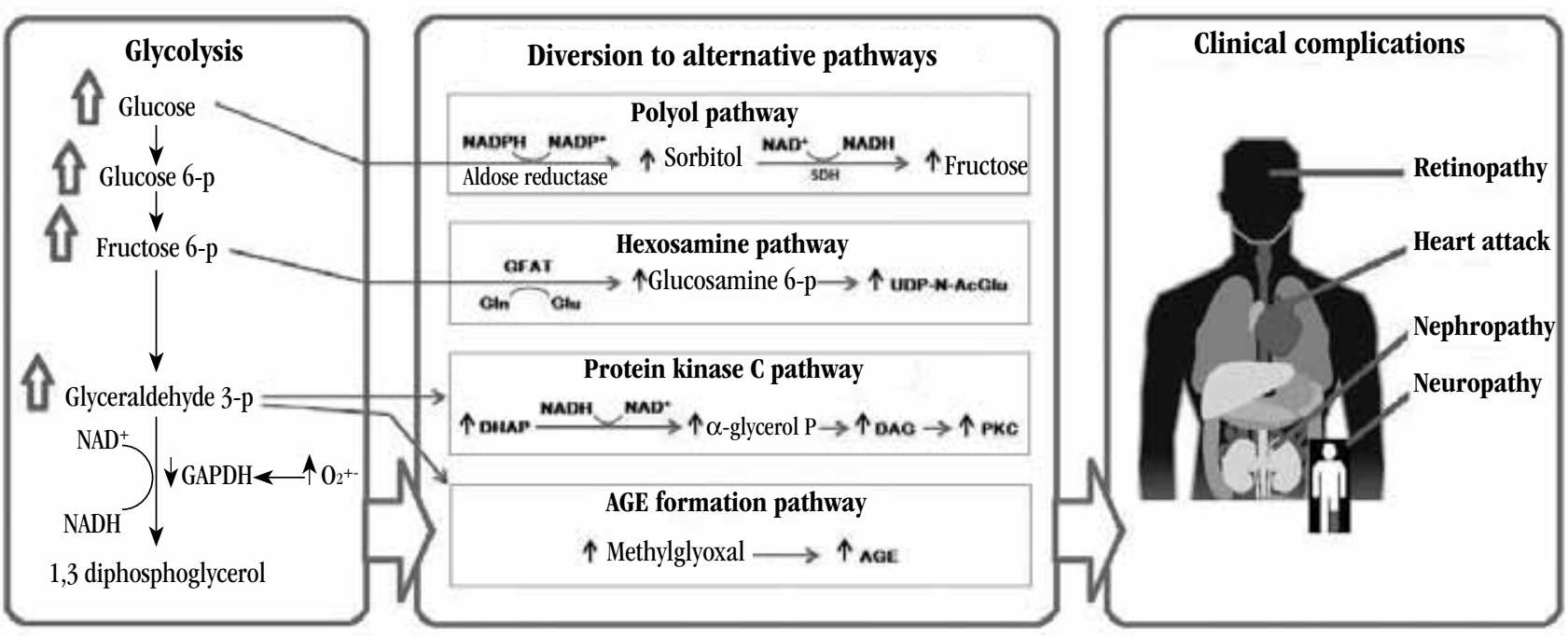

FIGURE 1 - Main metabolic pathways associated with vascular complications of diabetes

NAD+: oxidized nicotinamide adenine dinucleotide; NADH: reduced nicotinamide adenine dinucleotide; GAPDH: glyceraldehyde-3-phosphate dehydrogenase; GFTA: glutaminefructose-6-phosphate amidotransferase; Gln: glutamine; Glu: glutamate; UDP-N-AcGlu: fructose 6-phosphate to UDP-N-acetylglucosamine; DHAP: dihydroxyacetone phosphate; DAG: diacylglycerol; PKC: protein kinase C; AGEs: advanced glycation end-products. 
in smooth muscle cells; 2) involvement of blood flow due to the reduction of endothelial activity of nitric oxide synthase (NOS) and/or due to the increase in the synthesis of endothelin-1; 3) thickening of endothelium basal membrane due to the increase in the production of collagen and induced fibronectin by transforming growth factor beta (TGF- $\beta$ ) as well as leukocyte adhesion and angiogenesis ${ }^{(31)}$.

c) increase in the influx of hexosamine pathway - UDP-NAcGlu formed when there is excess of intracellular glucose indirectly regulates protein expression such as TGF- $\beta$ and the plasminogen activator inhibitor I (PAI-I), involved in diabetes vascular dysfunction. Moreover, hexosamine pathway is associated with the rise in oxidative stress $^{(6,47)}$.

d) non-enzymatic glycation of proteins and AGEs formationAGEs formed after long periods of chronic hyperglycemia activate signaling through binding with several receptors, and RAGE is the most characterized one. AGE-RAGE binding promotes oxidative stress and stimulates the release of cytokines and growth factors by several cells such as macrophages, renal mesangial and vascular endothelium cells. These components trigger inflammatory processes and endothelial dysfunction, the basis of DM physiopathology ${ }^{(6,69,78)}$.

e) the increase in oxidative stress caused by superoxide production $\left(\mathrm{O}_{2}-\right)$ - oxidative stress is defined as the overproduction of oxygen-reactive species (ORE) and/or decrease in the mechanisms of antioxidant defence. It seems to be involved in all previously mentioned pathways activated by hyperglycemia, inasmuch as the overproduction of $\mathrm{O}_{2}$-mitochondrial electron transport chain occurs in all of them ${ }^{(7)}$. The oxidative process causes insulin resistance, glucose intolerance, beta and mitochondrial cell dysfunction, which also foster the development of vascular complications in diabetic patients ${ }^{(57)}$.

\section{AGEs}

AGEs are products that result from non-enzymatic glycation reactions and protein, lipid and nucleic acid glycoxidation. The most widely known is Millar reaction, in which a carbohydrate reacts with extracellular proteins in a non-enzymatic way, a process called glycation. This reaction initiates the reversible formation of a Schiff base between a carbohydrate and a protein amino group, which becomes a stable intermediate keto amine, designated Amadori product. After a complex and repeated cascade of dehydration, condensation, oxidation and cyclization reactions, which may take months, advanced glycation end-products (AGEs) are formed, also known as advance Maillard reaction end-products.

An alternative pathway to AGEs formation is through glycolytic intermediate compounds such as highly reactive alpha dicarbonyl compounds (glyoxal, methylglyoxal and 3-deoxiglucosone), which are formed by several mechanisms such as degradation of Amadori products, oxidative stress and decomposition of phosphorylated intermediates ${ }^{(3)}$.

These compounds are considered the main intermediates in AGEs formation, insofar as they are more reactive to glucose. High glucose concentration, which is common among patients with poorly controlled diabetes, has been considered the primary event to the accelerated formation of $\mathrm{AGES}^{(7)}$.

AGEs are derived from the binding of a carbohydrate with lysine or arginine protein residues, and some of them may crosslink proteins. It is possible that other similar products may be formed during glycation reaction, targeting nucleophilic groups of proteins such as lateral chains of histidine, serine, threonine, tryptophan and tyrosine $^{(71)}$. Figure 2 shows the chemical structure of main AGEs.

AGEs derived from lysine are the following: Ne-carboxyethyllysine (CEL), pyrroline, glyoxal-derived lysine dimer (GOLD), methylglyoxal lysine dimer (MOLD), 3-deoxyglucosone derived lysine dimer (DOLD). Ne-carboxymethyl-lysine (CML) is the best characterized AGE, presenting the highest serum concentration in humans. AGEs derived from arginine are the following: glyoxal-derived hydroimidazolone (G-H1), methilglyoxal derived hydroimidazolone (MG-H1) and 3-deoxyglucosone derived hydroimidazolone (3DG-H1). Other AGEs such as 1-alkyl-2-formyl-3, 4-glycosyl pyrrole (AFGP), 2-(2-fluoril)-4, 5-furanyl-imidazole-1(FPI) and pentosidine are fluorescent ${ }^{(15,48)}$. Figure 3 illustrates the phases of Maillard reaction with the formation of three different AGEs.

In Figure 3 it is possible to notice that the arginine and lysine free residues of proteins react with aldehyde groups of sugars producing unstable Schiff base. This compound is stabilized through Amadori rearrangement, resulting in stable product. Multiple rearrangements cause alteration in the sugar portion. Some of them cross link with proteins and are fluorescent.

The concentration of highly reactive carbonyl compounds also contributes to the accumulation of advanced glycation products. The reduction in turnover or protein return rate is one of the most harmful effects associated with the glycation of these molecules ${ }^{(69)}$.

AGEs induce several cellular responses, not only the endocytic uptake and degradation processes, but also cytokine induction, growth factors and oxidative stress, which are connected with the development of diabetic vascular complications ${ }^{(48)}$.

According to Hung et al. ${ }^{(28)}$, high concentrations of AGEs induce $\mathrm{T}$ lymphocyte apoptosis. In the process of AGE-induced apoptosis, the involvement of oxidative stress was identified, an effect that may be blocked by antioxidants.

Receptor-dependent mechanisms are probably involved in AGE-induced tissue dysfunction ${ }^{(24)}$, stimulating several biological phenomena in monocytes/macrophages, endothelial cells and mesangial cells ${ }^{(29)}$.

Several cellular receptors that present binding AGE capacity have been identified in different cell types, including RAGE - AGE receptor, complex of AGE receptors (AGE-R1, AGE-R2 and AGE-R3), galectin-3 (similar to AGE-R3), SRA, glycoprotein III-b (CD-36) and lectin-like oxidized low density lipoprotein receptor 1(LOX-1) ${ }^{(17)}$. AGE-R1, which is also designated OST-48, functions as an oligosaccharide carrier. AGE-R2 receptor is also called protein kinase c substrate $80 \mathrm{~K}-\mathrm{H}$. 


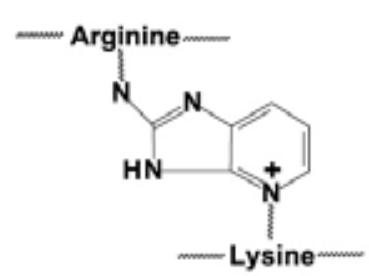

Pentosidine

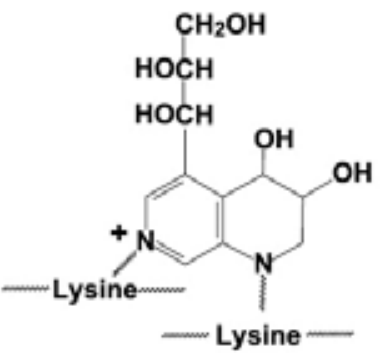

Crosslines
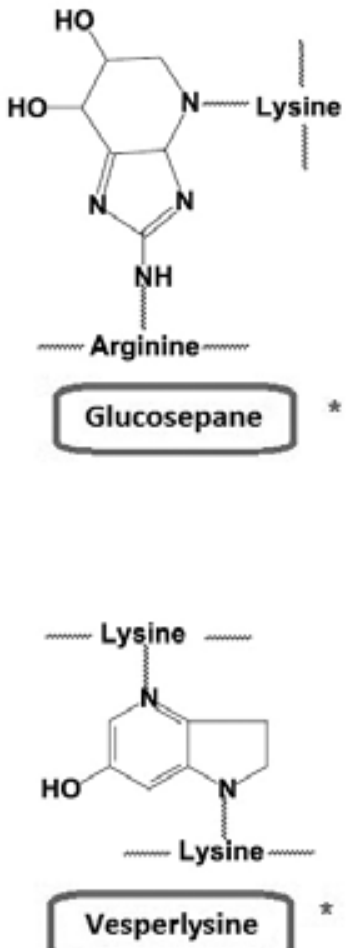

Vesperlysine

$\mathrm{CH}_{2} \mathrm{OH}$

$\mathrm{HOCH}$

$\mathrm{HOCH}$

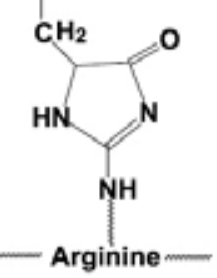

3DG-H1
* FLUORESCENT<smiles>CC[14C](C)NC1=NC(CC(O)CO)C(=NC)N1</smiles>

DOGDIC
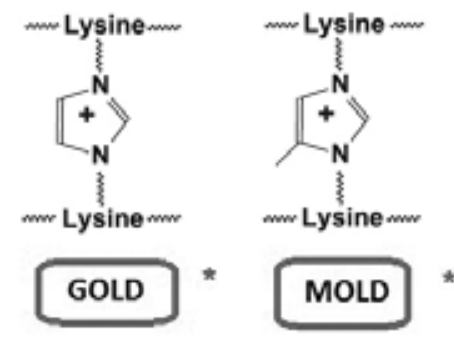

* NON-FLUORESCENT

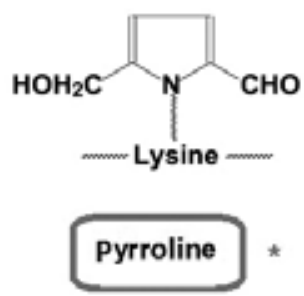<smiles>CNC(CNc1nc(C)c(O)c(C)n1)C(C)=O</smiles>

Argpyrimidine

FIGURE 2 -Chemical structure of main fluorescent and non-fluorescent AGEs

AGEs highlighted in red are fluorescent; those highlighted in grey are non-fluorescent.

DOGDIC: 3-deoxyglucosone derived imidazoline crosslink; GOLD: glyoxal lysine dimer; MOLD: methylglyoxal-lysine dimer; CML: carboxymethyl-lysine; CEL: carboxyethyllysine; 3DG-H1: 3-deoxyglucosone derived hydroimidazolone.

Adapted from THORPE, S. R.; BAYNES, J. W. (2003)(71).

Only RAGE and galectin-3 receptors do not fit in the denomination of scavenger receptors. AGE binding cell receptors may be classified into two types: receptor that bind AGEs and initiate cellular activation such as RAGE and those that bind and degrade AGEs such as AGE-R1 depuration receptors, scavenger receptor-II (ScR-II), endocytic receptor fasciclin EGF-like, laminin-type EGF-like, and link domaincontaining scavenger receptor 2 (FEEL-2) ${ }^{(65)}$.
The best characterized AGE receptor is RAGE. There are evidences that the interaction AGE-RAGE induces inflammation and oxidative stress, which causes AGE formation and accumulation, hence RAGE overexpression in diabetic patients. This feedback loop creates a vicious circle that may explain the phenomenon called metabolic memory in diabetic vascular complications, in which even after a period of glycemic control, vascular complications do not recede ${ }^{(76)}$. 


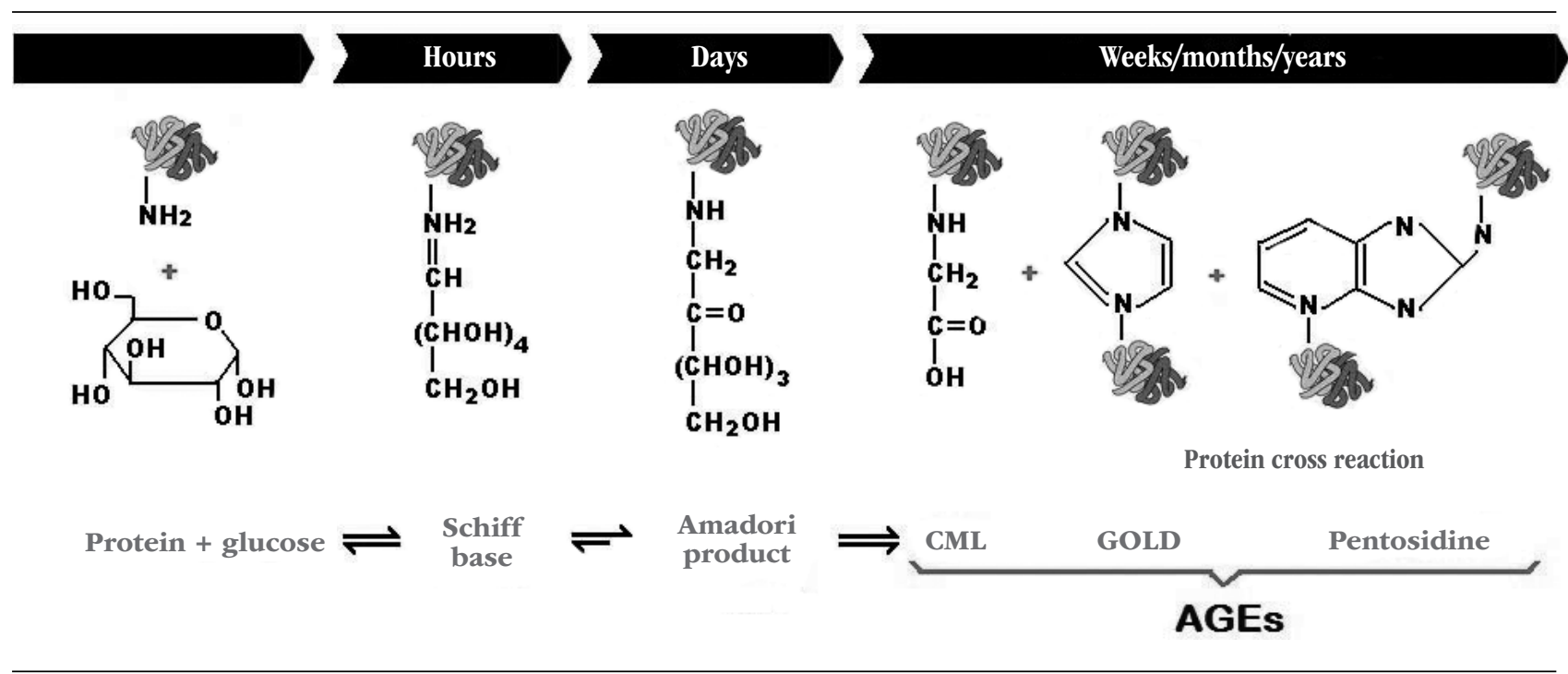

FIGURE 3 - Stages of glycation reaction (Maillard reaction)

CML: carboxymethyllysine; GOLD: glyoxal-lysine dimer; AGEs: advanced glycation end-products.

\section{RAGE receptor}

\section{Structure of RAGE protein}

RAGE is a type 1 transmembrane protein (with N-terminal extracellular domain) of approximately $45 \mathrm{KDa}$ and 404 amino acid residues, originally isolated in the bovine pulmonary endothelium ${ }^{(52)}$. RAGE protein is a superfamily member of cell surface immunoglobulins, whose expression is activated in several pathologies such as atherosclerosis and Alzheimer's disease ${ }^{(43)}$. RAGE is characterized as multi-binding, and apart from interacting with Age, it also interacts with High Mobility Group-box 1 proteins (HGN-box1) such as amphoterin, $\beta$-amyloid fibrils, S100/calgranulins, transthyretin and a leukocyte integrin, macrophage antigen-1 (Mac-1) ${ }^{(33)}$.

RAGE protein has three domains: binding to extracellular ligands (amino acids 1 to 339), hydrophobic transmembrane (amino acids 340 to 361) and highly charged intracellular cytoplasmatic hydrophobic (amino acids 362 to 404) ${ }^{(33)}$. The cytoplasmatic domain of RAGE is critical for ligand-induced intracellular signaling. Deletions of this domain result in RAGE receptor in negative state, in other words, they block the induction of intracellular signaling and, therefore, the receptor efficacy ${ }^{(37)}$. The extracellular domain is made of a N-terminal signal peptide (amino acids 1 to 22), a type $V$ immunoglobulin domain (variable, amino acids 23 to 116) and two type $\mathrm{C}$ immunoglobulin domains (constant) stabilized by disulfide bridges between cysteine residues (amino acids 124 to 221 in $\mathrm{C1}$ domain and amino acids 227 to 317 in $\mathrm{C} 2$ domain). The domain $\mathrm{V}$ presents two alleged biding sites for glycation N-binding products, and the main domain of interaction with ligands ${ }^{(37)}$, although the interaction of type $\mathrm{C}$ domains with ligands has also been reported ${ }^{(58)}$.

RAGE is expressed in a wide variety of cell types such as endothelial cells, mononuclear phagocytes, hepatocytes, lymphocytes, vascular smooth muscle cells, glomerular cells or podocytes and neurons in homeostasis ${ }^{(43)}$. The pulmonary tissue presents the highest RAGE expression ${ }^{(8,43)}$. In normal tissue and vessels, RAGE expression is minimal, although it is self-regulated by the interaction of RAGE with ligands through a mechanism activated by intracellular redox, that is to say, where there is an accumulation of pro-inflammatory ligands, there will be a higher RAGE expression. When there in a rise in cellular activation or stress, as it occurs in normal development, diabetes, cardiovascular disease, tumors and inflammation, RAGE expression is markedly higher in affected cells ${ }^{(9)}$.

Ligand and RAGE binding induces several types of signaling cascades, depending on cell type and pathophysiological condition. As described by Zeng et al. ${ }^{(79)}$, signaling cascades include several members of the following families: Mitogen-Activated Protein Kinase (MAPK), Janus Kinase/Signal Transducer and Activator of Transcription (JAK/ STAT) and Rho GTPases. Furthermore, other transcriptional factors such as nuclear factor kappa B (NF-kB) and early growth response protein 1 (Egr-1) are also included. There are evidences that MAKP, extracellular signal regulated kinase-1 (ERK 1) and 2 (ERK 2) may bind directly with RAGE cytoplasmic domain, though the interaction with formin homologue protein, diaphanous 1 , seems to be the most probable candidate for the transmission of signaling ligand via RAGE interaction ${ }^{(26)}$. These associated signaling pathways induce RAGE receptor to the activation of several pro-inflammatory genes and cellular phenotypic changes, including stimulus to migration, invasion, proliferation and apoptosis ${ }^{(23)}$.

RAGE ligands may form oligomers to induce signaling and RAGE may be in multimeric form on cellular surface. Furthermore, it has been demonstrated that RAGE homodimerization occurs via type $V$ domain and this dimerization is major for the signaling activation via $\mathrm{MAPK}^{(81)}$. 


\section{RAGE gene structure and organization}

Human RAGE gene was mapped in chromosome 6p21.3, located in the main histocompatibility complex between class II and III regions (GenBank/EMBL - Data Bank Accession Number D28769). This gene comprises $1.7 \mathrm{~kb}, 11$ exons and 10 introns of variable size in 3'UTR region, which may reach $4 \mathrm{kpb}$. Moreover, immunoglobulin type $V$ domain is codified by the second and third exons ${ }^{(66)}$.

Over 50 genetic variants have been described for RAGE gene ${ }^{(22,35,44)}$. The functional single nucleotide polymorphisms (SNPs), including variation I codon 82 (G82S, rs 2070600), resulting from the amino acid exchange of glycine for serine in domain $\mathrm{V}$ and two polymorphic regions in the promoting region, $-429 \mathrm{~T}>\mathrm{C}$ (rs 1800625) and $-374 \mathrm{~T}>\mathrm{A}$ (rs 1800624), have been extensively researched in association with pathologies ${ }^{(25)}$. The allele $374 \mathrm{~A}$ of RAGE promoter has been associated as a protector against macrovascular damage in patients with DM type $2^{(44,55)}$ and the allele $-429 \mathrm{C}$ with diabetes type 1 (DM1) ${ }^{(56)}$. More recently, the genome-wide association studies (GWAS) has shown the association of polymorphism G82S with pulmonary function ${ }^{(22)}$.

Other polymorphism associations with RAGE gene have also been reported: breast tumor ${ }^{(68)}$, pancreas tumor ${ }^{(38)}$, gastric tumor ${ }^{(21)}$, multiple sclerosis $^{(42)}$ and diabetic complications ${ }^{(35)}$.

\section{SRAGE}

Apart from RAGE expressed in cell membranes, which is denominated complete RAGE, several isoforms have been described, mainly its soluble form (sRAGE). It contains the same regions $\mathrm{V}$ and $\mathrm{C}$ found in RAGE, though it does not present transmembrane helix and cytosolic tail. There are two types of sRAGe: esRAGE, also known as sRAGE_v1, and cRAGE. A splicing variant codifies the secreted esRAGE form and cleavage of RAGE membrane through metalloprotease produces $\mathrm{CRAGE}^{(60,80)}$.

\section{RAGE soluble isoforms}

The formation of secreted variant isoforms is a common phenomenon among membrane receptors. These soluble or secreted variants may act as regulators, agonists or antagonists of the functional form linked with the membrane ${ }^{(62)}$. Multiple variants of splicing RAGE have been identified in humans and mice ${ }^{(27,33,46,62)}$.

Malherbe et al. ${ }^{\left({ }^{(4)}\right)}$ were the first to describe a soluble variant, denominated human RAGE secreted form (hRAGEsec). Over time other sRAGEs were described, namely esRAGE ${ }^{(77)}$. Only sRAGE_vl, previously denominated esRAGE, was ever found soluble in plasma. This soluble isoform is produced owing to alternative splicing of intron 9, with removal of exon 10 , which modifies the reading phase of the transcript. It results in premature stop codon in intron 9 , which in the translation would correspond to transmembrane helix and cytosolic tail of complete RAGE. Accordingly, there will be the introduction of 16 new amino acids in the C-terminal region and the generation of soluble isoforms. This sequence of amino acids differentiates membrane RAGE from splice-generated RAGE, allowing the production of specific commercial antibodies for esRAGE, which do not detect membrane RAGE. Experiments with Western Blot technique have demonstrated that esRAGE (sRAGE_vl) is secreted and migrates as a protein of approximately $48 \mathrm{kDa}$ (compared with $55 \mathrm{kDa}$ of the whole receptor) ${ }^{(26)}$. The current terminology for esRAGE isoform is RAGE_v1, though the term esRAGE has been kept, probably due to the fact that the manufactured test has this description.

\section{RAGE soluble isoforms by proteolysis}

Proteolysis of RAGE occurs constitutively and it is stimulated by the activation of calcium-dependent $\mathrm{PCK}^{(80)}$. The proteins from disintegrin and metalloprotease domain (ADAM) superfamily are denominated this way, insofar as they have disintegrin and metalloprotease as structural domains. Moreover, they play a regulatory role on cell surface ${ }^{(74)}$. They may influence cell-cell and cell-matrix interactions by cleavage, remodeling of extracellular membrane proteins and possibly through the interaction with matrix adhesion molecules. Alphasecretases (ADAM-10) and metalloproteinase 9 (MMP9) have been identified as accountable for proteolytic cleavage of RAGE with ectodomain liberation. Thus, the remaining transmembrane domain is cleaved by gamasecretases, being released into the cytoplasm. This changes the subcellular location of intracellular domain, inducing apoptosis ${ }^{(39,60)}$.

The complete isoform is found in higher concentrations in the pulmonary tissue and in lower concentrations in other tissues. It has also been proposed that esRAGE may be the second most prevalent isoform in tissues, after complete RAGE ${ }^{(26)}$. Splicing RAGE is tissue dependent, which may justify these differences ${ }^{(60)}$.

Six RAGE isoforms have been detected in the human brain: one complete isoform (containing all domains), one isoform with domain C, two soluble isoforms (cRAGE and esRAGE) and two N-truncated isoforms ${ }^{(18)}$. The most predominant soluble isoform in the human serum is the proteolytic cleavage (cRAGE) ${ }^{(60)}$. Figure 4 summarizes RAGE isoforms.

Based on Figure 4, it is possible to notice that RAGE is a transmembrane receptor that interacts with several ligands such as AGE, high mobility group box 1 (HMGB1) and S100, promoting cellular signaling. Some isoforms such as dominant-negative RAGE (DN-RAGE) interact with ligands, though they do not foster signal transduction by the absence of cytosolic tail. Delta-RAGe isoform without domain $\mathrm{V}(\triangle \mathrm{N}-\mathrm{RAGE})$ precludes the interaction with ligands. RAGE soluble isoforms (sRAGe) interact with ligands in circulation, hence cellular signal transduction does not occur. There are two RAGE soluble isoforms: esRAGE and cRAGE. The former is generated by alternative splicing of exon 9 from RAGE gene. The latter is generated through proteolytic cleavage by metalloproteases.

\section{Function of RAGE soluble isoforms}

The main RAGE soluble forms (cRAGE and esRAGE) have the alleged function of binding with AGEs and other RAGE ligands, preventing the latter from interacting with complete RAGE receptor, 


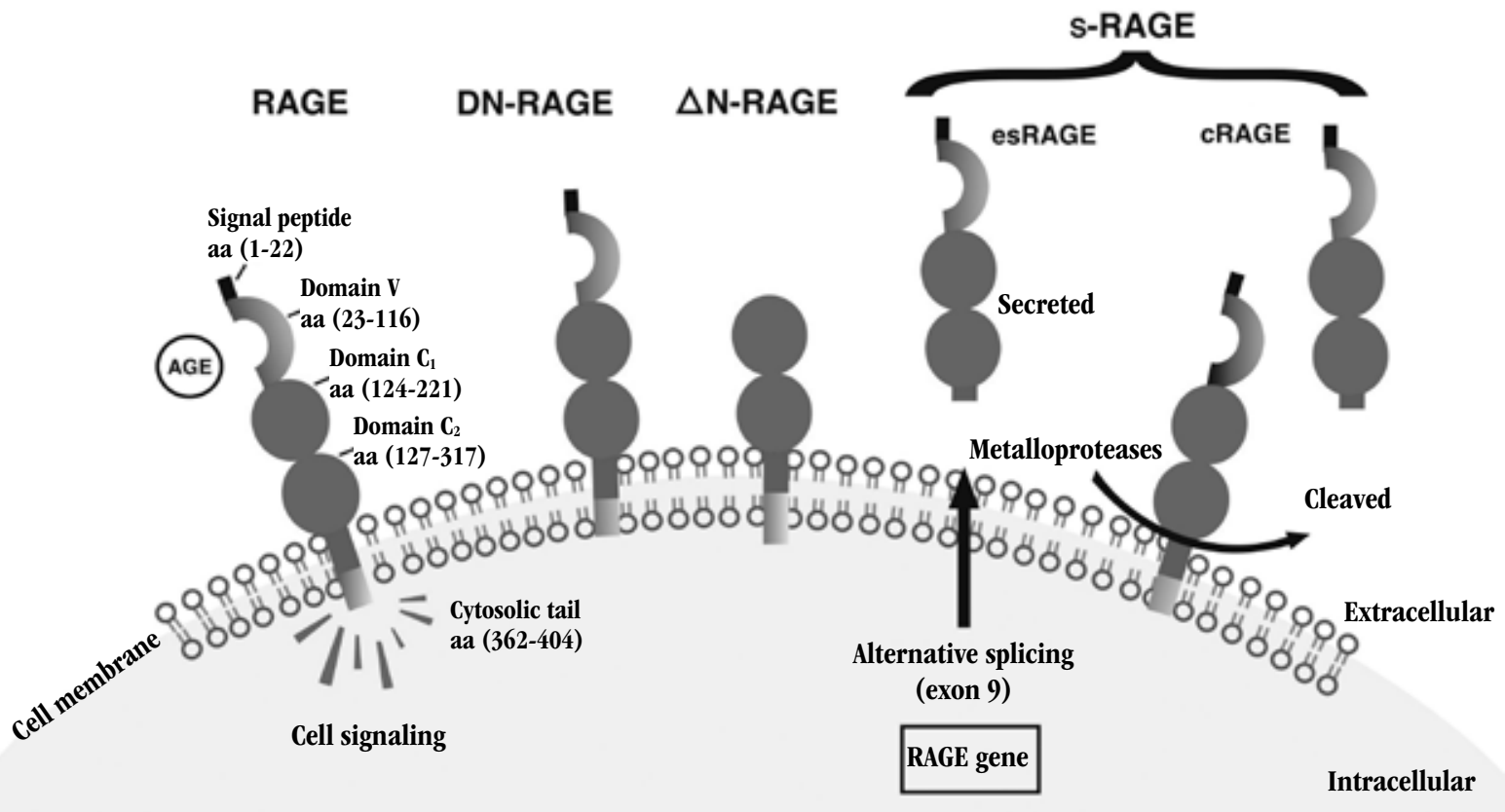

FIGURE 4 - RAGE isoforms

$R A G E$ : receptor of advanced glycation end-products; DN-RAGE: dominant negative RAGE; $\triangle N$-RAGE: delta-RAGE isoform without domain V; sRAGE: soluble RAGE isoforms; esRAGE: endogenous secretory RAGE; cRAGE: cleaved RAGE; AGE: advanced glycation end-product.

hence protecting the cell against damages caused by the activation of RAGE receptor. However, there is still limited information on the correlation among AGE, RAGE and sRAGe ${ }^{(2)}$.

A common biological characteristic is the action of soluble receptors as baits for their cellular surface homologues. Even before the discovery that RAGE occurred in soluble isoforms, a recombinant soluble isoform (sRAGE) was produced and used as RAGE inhibitor ${ }^{(73)}$. It has been demonstrated that the use of recombinant sRAGE acts as a decoy for RAGE ligands and, therefore, blocks the development and progression of several pathological states in animal models, including cardiovascular disease, DM, neural dysfunctions and cancer ${ }^{(41)}$. Accordingly, as esRAGE exists as a soluble isoform of RAGE, it has been proposed that the latter blocks the signaling effects induced by RAGE ligands ${ }^{(27)}$. These soluble isoforms seem to fix ligands more easily in comparison with complete $\mathrm{RAGE}^{(8)}$. Initial experiments have revealed that esRAGE isoforms share the same binding domain structure with RAGE ligands that are fixed on the cell membrane (glyceraldehyde derived AGE-BSA) and these isoforms may act as baits by binding RAGE ligands, inasmuch as a endothelial cell lineage (ECV304) prevented the cellular signaling caused by AGE-RAGE binding ${ }^{(78)}$.

Evidences point to recombinant sRAGE as a potent agent to the prevention of carcinogenesis and tumor metastasis. Models of tumor formation in vitro and in vivo demonstrated that esRAGE reduced carcinogenesis significantly. Moreover, it inhibited signaling of RAGE ligands with repair of angiogenic damage commonly associated with diabetes. These data suggest that esRAGE acts as an endogenous baiting system on cell surface ${ }^{(34)}$.
The identification of mechanisms involved in the production and regulation of esRAGE concentration may lead to the development of new therapeutic approaches. Mechanisms that increase the production of this isoform may be useful in the inhibition of RAGE ligand signaling in several pathological states. The specific mechanism that regulates esRAGE production by alternative splicing is unknown. Ohe et al. ${ }^{(54)}$ have recently demonstrated that a guaninerich cis element $(G)$ in intron 9 leads esRAGE splicing. Mutations in this sequence result in the rise of esRAGE production and inhibition of complete RAGE production. G-rich regions may act as binding sites for heterogeneous nuclear ribonucleoprotein $\mathrm{H}$ protein families (hnRNP H), which process pre- messenger ribonucleic acid (RNAm) into the mature form for nuclear export ${ }^{(72)}$. Binding assays demonstrated that nuclear extracts of human embryonic kidney cells (HEK293) confirmed the interaction between the G-rich sequence present in intron 9 of RAGE and hnRNP $\mathrm{H}^{(54)}$. Santilli et al. ${ }^{(61)}$ claim that RAGE activation by binding with its ligands may inhibit esRAGE production in order to self-amplify the pathogenetic response without any competition for the ligand. Furthermore, they highlight that a redox cell environment allows the reduction of esRAGE expression, insofar as the alternative splicing mechanism is highly sensitive to redox balance. However, it is controversial whether the regulations occur this way or whether it follows another structure in which increased RAGE expression and, therefore, the increase in cell damage, would stimulate the generation and liberation of soluble RAGEs.

Cardio-protective medicines may alter esRAGE concentrations. This indicates that the concentration dosage of these soluble forms 
in human serum may be a potential biomarker for RAGE-associated pathologies $^{(34)}$.

The association of total sRAGE concentration with pathological states was first described by Falcone et al. ${ }^{(16)}$, whose experiments corroborated that reduced total sRAGE plasma concentrations were associated with a higher risk of coronary artery disease. Afterwards, sRAGE plasma concentration was associated with several pathological conditions such as DM1 and cardiovascular diseases ${ }^{(70)}$, tumors $^{(32)}$, acute pulmonary disease ${ }^{(12)}$ and renal disease ${ }^{(53,64)}$. Additionally, the increase in total sRAGE concentration has been correlated with extreme longevity, suggesting a major role of RAGE/sRAGe in the aging process ${ }^{(19)}$. The Table below summarizes the data from some investigations into the association between soluble RAGE and diabetes.

Studies that focus specifically on esRAGE dosage have demonstrated similar associations. Low esRAGe plasma concentrations have been closely linked with intima and carotid atherosclerosis in diabetic patients or not ${ }^{(10,36)}$, metabolic syndrome ${ }^{(40)}$, anemia ${ }^{(63)}$ and autism $^{(4)}$

In diabetic patients with atherosclerosis, esRAge regulation and function may differ. Its high concentration is positively associated with the presence of coronary artery disease (CAD) in patients with DM type 2 (DM2) and inflammation biomarkers such as tumor necrosis factor-alpha (TNF- $\alpha$ ), monocyte chemotactic protein-1 (MCP-1) and soluble vascular cell adhesion molecule-1(sVCAM-1) ${ }^{(49,50)}$. Other investigations still suggest that sRAGE concentrations may be high in response to circulating AGEs, hence becoming a reliable vascular injury marker in patients with DM2 ${ }^{(51)}$. Additionally, it has been reported that an increase in sRAGe in children with DM1 may protect cells temporarily against injuries caused by AGEs and it may be sufficient to eliminate the excess of circulating $\mathrm{CML}^{(15)}$. Yet another research reported the inverse association between esRAGE concentrations and renal alterations in children with DM1, implying the importance of this isoform in early stages of diabetic nephropathy ${ }^{(20)}$. As AGEs regulate RAGE expression positively in several tissues and endogenous SRAGE may be produced by RAGE cleavage on cell surface through matrix metalloproteases, sRAGE may be positively associated with circulating AGEs, hence reflecting RAGE tissue expression. Therefore, this may explain some contradictions, although the mechanism is still unknown ${ }^{(51)}$.

Experiments carried out by Raposeiras-Roubín et al. ${ }^{(59)}$ associated SRAGE concentration with ischemia in patients with heart failure, disease severity and as an independent marker for coronary artery disease.

sRAGE quantification is assessed through immunoenzymatic methods. There are two commercial ELISA systems. sRAGe concentration is obtained with monoclonal antibody that recognizes the N-terminal portion of the protein (amino acids Gln24-Ala344), common to all soluble RAGE forms. Antibodies that bind to the C-terminal portion (16 amino acid residues 332-347) of RAGE protein identify esRAGE form. Specific assays for cRAGE are not available yet ${ }^{(5)}$.

\section{CONCLUSION}

Hyperglycemia modifies the cell redox balance, activates oxidative stress and interferes in the electron transport chain, originating a signaling cascade. The glycation process results in the formation of advanced glycation end-products that induce pro-inflammatory and pro-coagulant mechanisms, maximizing oxidative stress. Accordingly, the involvement of AGEs, RAGE receptor and, more recently, sRAGE is undisputed. However, studies involving soluble RAGE with diabetes and its vascular complications are inconclusive.

The administering of recombinant sRAGE has the potential to reduce late complications of DM such as arterial lesion. Currently, available commercial assays for the determination of soluble RAGE isoform concentrations detect only esRAGE and sRAGE isoforms. The soluble isoform obtained through enzymatic cleavage (cRAGe) is estimated by the difference between sRAGE and esRAGE isoforms.

Alterations in renal function affect esRAGE and sRAGE concentrations in an inverse relationship. The reduction in renal functions occurs in conjunction with the rise in esRAGe serum concentrations $^{(64)}$. The pathophysiological explanation for this phenomenon is unknown. The increase in esRAGE associated with reduction in renal function may indicate a reduction in clearing of this isoform as well as it may reflect the increase in the synthesis of these molecules linked with the pathological process of renal lesion.

The major studies involving human sRAGE have been transversal, with relatively small sample size and without patients' follow-up and serial determinations. Thus, future studies may be carried out in larger cohorts and with a prospective approach in order to assess the efficacy of soluble RAGE isoform concentrations as biomarkers associated with diabetic complications. 
TABLE - Summary of studies on the association between soluble RAGE isoforms and diabetes complications

\begin{tabular}{|c|c|c|c|c|c|}
\hline Isoforms & $\begin{array}{l}\text { Condition/ } \\
\text { pathology }\end{array}$ & Samples & Results & Study outcome & References \\
\hline esRAGE & $\begin{array}{l}\text { DM2, MS and } \\
\text { atherosclerosis }\end{array}$ & $\begin{array}{l}\text { Case: } 203 \text { diabetic patients } \\
\text { Control: } 134 \text { non-diabetic patients }\end{array}$ & $\begin{array}{l}\text { esRAGE mean and deviation } \\
\text { values (ng/ml) } \\
\text { Diabetic: } 0.176 \pm 0.092 \\
\text { Non-diabetic: } 0.262 \pm 0.110\end{array}$ & $\begin{array}{l}\text { Individuals with DM2 and glucose } \\
\text { intolerance presented reduced } \\
\text { concentrations of esRAGE and } \\
\text { were inversely associated with } \\
\text { atherosclerosis and severe MS } \\
\text { components }\end{array}$ & 40 \\
\hline sRAGE & $\begin{array}{l}\text { Non-diabetic and } \\
\text { CAD }\end{array}$ & $\begin{array}{l}\text { Case: } 328 \text { non-diabetic patients with CAD } \\
\text { Control: } 328 \text { healthy individuals paired } \\
\text { by age }\end{array}$ & $\begin{array}{l}\text { sRAGE median and variation values } \\
(\mathrm{pg} / \mathrm{ml}) \\
\text { Case: } 966(658-1,372) \\
\text { Control: } 1,335(936-1,954)\end{array}$ & $\begin{array}{l}\text { Reduced concentrations of total } \\
\text { sRAGE were independently } \\
\text { associated with CAD in non- } \\
\text { diabetic male patients }\end{array}$ & 16 \\
\hline sRAGE & $\mathrm{DM} 2$ and $\mathrm{CAD}$ & $\begin{array}{l}\text { Case: } 75 \text { Japanese patients with DM2 } \\
\text { Control: } 75 \text { healthy Japanese patients } \\
\text { paired by gender and age }\end{array}$ & $\begin{array}{l}\text { sRAGE mean and deviation values } \\
(\mathrm{pg} / \mathrm{ml}) \\
\text { Case: } 965.3 \pm 544.2 \\
\text { Control: } 415 \pm 150.4\end{array}$ & $\begin{array}{l}\text { sRAGE concentrations were higher } \\
\text { in DM2 and positively associated } \\
\text { with CAD }\end{array}$ & 49 \\
\hline sRAGE & DM1 and CVD & 3,100 adults with DM1 & $\begin{array}{l}\text { sRAGE mean and deviation values } \\
(\mathrm{pg} / \mathrm{ml}) 1,255 \pm 558\end{array}$ & $\begin{array}{l}\text { Higher concentrations of sRAGE } \\
\text { were independently associated with } \\
\text { CVD in DM1 }\end{array}$ & 70 \\
\hline $\begin{array}{l}\text { sRAGE and } \\
\text { esRAGE }\end{array}$ & DM2 and CVD & $\begin{array}{l}\text { Case: } 167 \text { patients with DM2 that } \\
\text { developed cardiovascular event during } \\
\text { the study } \\
\text { Control: } 551 \text { patients with DM2 that did } \\
\text { not develop cardiovascular event during } \\
\text { the study }\end{array}$ & $\begin{array}{l}\text { esRAGE median value }(\mathrm{ng} / \mathrm{ml}) \\
\text { Case: } 0.330(0.240-0.460) \\
\text { Control: } 0.330(0.240-0.430) \\
\text { sRAGE median and variation values } \\
\text { (pg/ml) } \\
\text { Case: } 1,404(1,097-1,877) \\
\text { Control: } 1,404(1,057-1,777)\end{array}$ & $\begin{array}{l}\text { Higher concentrations of } \\
\text { plasma sRAGE and esRAGE } \\
\text { were associated with coronary } \\
\text { disease incidence, but they were } \\
\text { not associated with infarction in } \\
\text { patients with com DM2 }\end{array}$ & 11 \\
\hline
\end{tabular}




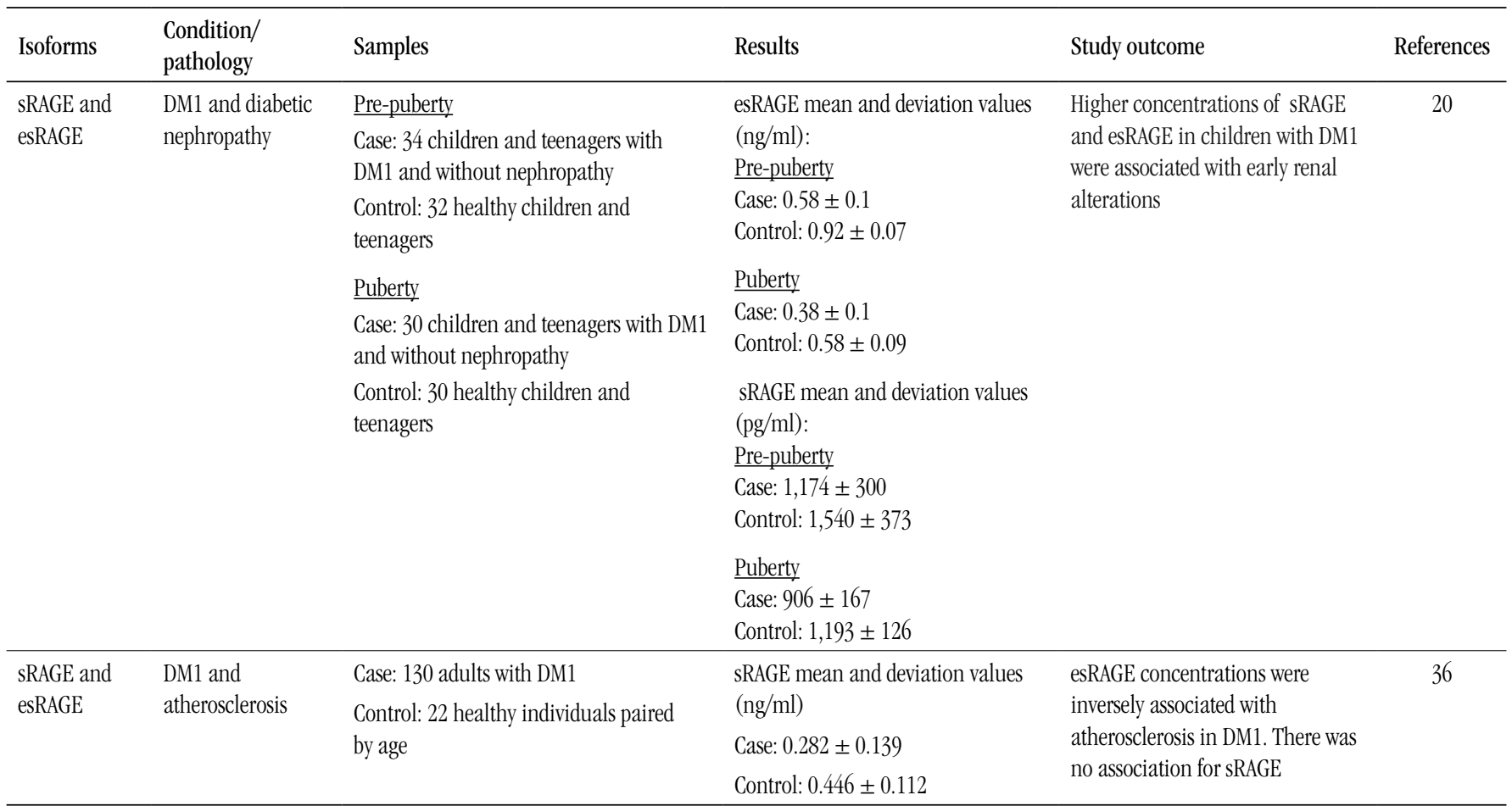

RAGE: receptor of advanced glycation end-products; esRAGE: endogenous soluble secretory RAGE (formed by splicing); DM2: diabetes mellitus type 2; SM: metabolic syndrome; DAC: artery coronary disease; RIS: intra-stent restenosis; SRAGE: soluble RAGE; DM1: diabetes mellitus type 1; AGEs: advanced glycation end-products; IAM: acute myocardial infarction; DCV: cardiovascular diseases.

\section{RESUMO}

A hiperglicemia crônica, presente em todas as formas de diabetes, favorece a formação de produtos finais de glicação avançada (AGEs). A interação de AGEs com o receptor de produtos finais glicosilados (RAGE) inicia uma cascata de processos pró-inflamatórios e pró-coagulantes que resultam em estresse oxidativo, o qual estimula a formação e o acúmulo de maior quantidade de moléculas de AGEs. Esse processo cíclico, denominado memória metabólica, pode explicar por que, mesmo após um período de bom controle glicêmico, as complicações vasculares associadas ao diabetes não regridem. O RAGE fixado nas membranas de várias células também está presente em isoformas solíveis (esRAGE e cRAGE), geradas por processamento alternativo do ácido desoxirribonucleico (DNA) ou por clivagem proteolítica. Esta revisão aborda os novos estudos sobre a função desses mediadores como potenciais biomarcadores para as complicações vasculares no diabetes.

Unitermos: receptor RAGE; isoformas solúveis de RAGE; isoformas de RAGE; complicações do diabetes.

\section{REFERENCES}

1. ADA. American Diabetes Association. Standards of medical care in diabetes

- 2012. Diabetes Care, v. 35, p. S11-63, 2012.

2. BIERHAUS, A.; NAWROTH, P. P. Multiple levels of regulation determine the role of the receptor for AGE (RAGE) as common soil in inflammation, immune responses and diabetes mellitus and its complications. Diabetologia, v. 52, p. 2251-63, 2009.

3. BOS, D. C.; de RANITZ-GREVEN, W. L.; de VALK, H. W. Advanced glycation end products, measured as skin autofluorescence and diabetes complications: a systematic review. Diabetes Technol Ther, v. 13, p. 773-9, 2011.

4. BOSO, M. et al. Alterations of circulating endogenous secretory RAGE and S100A9 levels indicating dysfunction of the AGE-RAGE axis in autism. Neurosci Lett, v. 410, p. 169-73, 2006.

5. BROWN, L. F.; FRASER, C. G. Assay validation and biological variation of serum receptor for advanced glycation end-products. Ann Clin Biochem, v. 45, p. 518-9, 2008.

6. BROWNLEE, M. Biochemistry and molecular cell biology of diabetic complications. Nature, v. 414, p. 813-20, 2001

7. BROWNLEE, M. The pathobiology of diabetic complications: a unifying mechanism. Diabetes, v. 54, p. 1615-25, 2005.

8. BUCKLEY, S. T.; EHRHARDT, C. The receptor for advanced glycation end products (RAGE) and the lung. J Biomed Biotechnol, v. 2010, p. 917108, 2010. 9. CERIELLO, A. Hypothesis: the metabolic memory, the new challenge of diabetes. Diabetes Res Clin Pract, v. 86, p. S2-6, 2009. 
10. CHOI, K. M. et al. Association between endogenous secretory RAGE, inflammatory markers and arterial stiffness. Int J Cardiol, v. 132, p. 96-101, 2009. 11. COLHOUN, H. M. et al. Total soluble and endogenous secretory receptor for advanced glycation end products as predictive biomarkers of coronary heart disease risk in patients with type 2 diabetes: an analysis from the CARDS trial. Diabetes, v. 60, p. 2379-85, 2011.

12. CREAGH-BROWN, B. C. et al. The RAGE axis in systemic inflammation, acute lung injury and myocardial dysfunction: an important therapeutic target? Intensive Care Med, v. 36, p. 1644-56, 2010.

13. DAILEY, G. Overall mortality in diabetes mellitus: where do we stand today? Diabetes Technol Ther, v. 13, p. S65-74, 2011.

14. DATASUS. Indicadores e dados básicos. IDB. Brasil. 2009. Disponível em: $<$ <http:/tabnet.datasus.gov.br/cgi/tabnet.exeidb2009/g01.def>. Acesso em: 7 jan. 2011. 15. DETTORAKI, A.; GIL, A. P.; SPILIOTIS, B. E. Association between serum levels of the soluble receptor (sRAGE) for advanced glycation endproducts (AGEs) and their receptor (RAGE) in peripheral blood mononuclear cells of children with type 1 diabetes mellitus. J Pediatr Endocrinol Metab, v. 22, p. 895-904, 2009.

16. FALCONE, C. et al. Plasma levels of soluble receptor for advanced glycation end products and coronary artery disease in nondiabetic men. Arterioscler Thromb Vasc Biol, v. 25, p. 1032-7, 2005.

17. FLEMING, T. H. et al. Reactive metabolites and AGE/RAGE-mediated cellular dysfunction affect the aging process - a mini-review. Gerontology, v. 57, p. 435-43, 2011.

18. GEFTER, J. V. et al. Comparison of distinct protein isoforms of the receptor for advanced glycation end-products expressed in murine tissues and cell lines. Cell Tissue Res, v. 337, p.79-89, 2009.

19. GEROLDI, D. et al. High levels of soluble receptor for advanced glycation end products may be a marker of extreme longevity in humans.J Am Geriatr Soc, v. 54, p. 1149-50, 2006.

20. GIANNINI, C. et al. The possible role of esRAGE and sRAGE in the natural history of diabetic nephropathy in childhood. Pediatr Nephrol, v. 27, p. 269-75, 2012.

21. GU, H. et al. Gly82Ser polymorphism of the receptor for advanced glycation end products is associated with an increased risk of gastric cancer in a Chinese population. Clin Cancer Res, v. 14, p. 3627-32, 2008.

22. HANCOCK, D. B. et al. Meta-analyses of genome-wide association studies identify multiple loci associated with pulmonary function. Nat Genet, v. 42 , p. 45-52, 2010.

23. HARJA, E. et al. Vascular and inflammatory stresses mediate atherosclerosis via RAGE and its ligands in apoE-/- mice.J Clin Invest, v. 118, p. 183-94, 2008. 24. HARTOG,J. W. et al. Advanced glycation end-products (AGEs) and heart failure: pathophysiology and clinical implications. Eur J Heart Fail, v. 9, p. 1146-55, 2007.

25. HUDSON, B. I. et al. Effects of novel polymorphisms in the RAGE gene on transcriptional regulation and their association with diabetic retinopathy. Diabetes, v. 50, p. 1505-11, 2001.

26. HUDSON, B. I. et al. Interaction of the RAGE cytoplasmic domain with diaphanous-1 is required for ligand-stimulated cellular migration through activation of Rac1 and Cdc42.J Biol Chem, v. 283, p. 34457-68, 2008a.

27. HUDSON, B. I. et al. Identification, classification, and expression of RAGE gene splice variants. FASEB J, v. 22, p. 1572-80, 2008b.

28. HUNG, L. F. et al. Advanced glycation end products induce T cell apoptosis: Involvement of oxidative stress, caspase and the mitochondrial pathway. Mech Ageing Dev, v. 131, p. 682-91, 2010.

29. IACOBINI, C. et al. Advanced lipoxidation end-products mediate lipidinduced glomerular injury: role of receptor-mediated mechanisms. J Pathol, v. 218 , p. 360-9, 2009.

30. JAX, T. W. Metabolic memory: a vascular perspective. Cardiovasc Diabetol, v. 9 , p. $51,2010$.
31. JEONG, I. K.; KING, G. L. New perspectives on diabetic vascular complications: the loss of endogenous protective factors induced by hyperglycemia. Diabetes Metab J, v. 35, p. 8-11, 2011.

32. JIAO, L. et al. Evidence that serum levels of the soluble receptor for advanced glycation end products are inversely associated with pancreatic cancer risk: a prospective study. Cancer Res, v. 71, p. 3582-9, 2011.

33. KALEA, A. Z.; SCHMIDT, A. M.; HUDSON, B. I. RAGE: a novel biological and genetic marker for vascular disease. Clin Sci (Lond), v. 116, p. 621-37, 2009.

34. KALEA, A. Z.; SCHMIDT, A. M.; HUDSON, B. I. Alternative splicing of RAGE: roles in biology and disease. Front Biosci, v. 17, p. 2756-70, 2011.

35. KALOUSOVÁ, M. et al. Genetic predisposition to advanced glycation end products toxicity is related to prognosis of chronic hemodialysis patients. Kidney Blood Press Res, v. 33, p. 30-6, 2010.

36. KATAKAMI, N. et al. Serum endogenous secretory RAGE level is an independent risk factor for the progression of carotid atherosclerosis in type 1 diabetes. Atherosclerosis, v. 204, p. 288-92, 2009.

37. KISLINGER, T. et al. N(epsilon)-(carboxymethyl)lysine adducts of proteins are ligands for receptor for advanced glycation end products that activate cell signaling pathways and modulate gene expression. J Biol Chem, v.274, p. 31740-9, 1999 .

38. KRECHLER, T. et al. Soluble receptor for advanced glycation end-products (sRAGE) and polymorphisms of RAGE and glyoxalase I genes in patients with pancreas cancer. Clin Biochem, v. 43, p. 882-6, 2010.

39. KOJRO, E.; POSTINA, R. Regulated proteolysis of RAGE and AbetaPP as possible link between type 2 diabetes mellitus and Alzheimers disease. JAlzheimers Dis, v. 16, p. 865-78, 2009.

40. KOYAMA, H. et al. Plasma level of endogenous secretory RAGE is associated with components of the metabolic syndrome and atherosclerosis. Arterioscler Thromb Vasc Biol, v. 25, p. 2587-93, 2005.

41. LANATI, N. et al. Soluble RAGE-modulating drugs: state-of-the-art and future perspectives for targeting vascular inflammation. Curr Vasc Pharmacol, v. 8, p. 86-92, 2010.

42. LI, K. et al. A functional p.82G $>$ S polymorphism in the RAGE gene is associated with multiple sclerosis in the Chinese population. Mult Scler, v. 17, p. 914-21, 2011.

43. LINDSEY,J. B. et al. Receptor for advanced glycation end-products (RAGE) and soluble RAGE (sRAGE): cardiovascular implications. Diab Vasc Dis Res, v. 6, p. 7-14, 2009.

44. LU, W.; FENG, B. The -374A allele of the RAGE gene as a potential protective factor for vascular complications in type 2 diabetes: a meta-analysis. Toboku J Exp Med, v. 220, p. 291-7, 2010.

45. McCARTHY, M. I. Genomics, type 2 diabetes, and obesity. $N$ Engl J Med, v. 363, p. 2339-50, 2010.

46. MALHERBE, P. et al. cDNA cloning of a novel secreted isoform of the human receptor for advanced glycation end products and characterization of cells co-expressing cell-surface scavenger receptors and Swedish mutant amyloid precursor protein. Brain Res Mol Brain Res, v. 71, p. 159-70, 1999.

47. MARCOVECCHIO, M. L.; LUCANTONI, M.; CHIARELLI, F. Role of chronic and acute hyperglycemia in the development of diabetes complications. Diabetes Technol Ther, v. 13, p. 389-94, 2011.

48. MIYAZAWA, T. et al. Lipid glycation and protein glycation in diabetes and atherosclerosis. Amino Acids, v. 42, p. 1163-70, 2012.

49. NAKAMURA, K. et al. Elevation of soluble form of receptor for advanced glycation end products (sRAGE) in diabetic subjects with coronary artery disease. Diabetes Metab Res Rev, v. 23, p. 368-71, 2007a.

50. NAKAMURA, K. et al. Serum levels of sRAGE, the soluble form of receptor for advanced glycation end products, are associated with inflammatory markers in patients with type 2 diabetes. Mol Med, v. 13, p. 185-9, $2007 \mathrm{~b}$. 
51. NAKAMURA, K. et al. Serum levels of soluble form of receptor for advanced glycation end products (SRAGE) are positively associated with circulating AGEs and soluble form of VCAM-1 in patients with type 2 diabetes. Microvasc Res, v. 76, p. 52-6, 2008.

52. NEEPER, M. et al. Cloning and expression of a cell surface receptor for advanced glycosylation end products of proteins. J Biol Chem, v. 267, p. 4998-5004, 1992.

53. NISHIZAWA, Y.; KOYAMA, H. Endogenous secretory receptor for advanced glycation end-products and cardiovascular disease in end-stage renal disease. J Ren Nutr, v. 18, p. 76-82, 2008.

54. OHE, K. et al. Regulation of alternative splicing of the receptor for advanced glycation endproducts (RAGE) through G-rich cis-elements and heterogeneous nuclear ribonucleoprotein H.J Biochem, v. 147, p. 651-9, 2010

55. PICHETH, G. et al. The $-374 \mathrm{~A}$ allele of the receptor for advanced glycation end products (RAGE) gene promoter is a protective factor against cardiovascular lesions in type 2 diabetes mellitus patients. Clin Chem Lab Med, v. 45, p. 1268-72, 2007a

56. PICHETH, G. et al. The $-429 \mathrm{~T}>\mathrm{C}$ polymorphism of the receptor for advanced glycation end products (RAGE) is associated with type 1 diabetes in a Brazilian population. Clin Chim Acta, v. 383, p. 163-4, 2007 b.

57. RAINS, J. L.; JAIN, S. K. Oxidative stress, insulin signaling, and diabetes. Free Radic Biol Med, v. 50, p. 567-75, 2011.

58. RAMASAMY, R.; YAN, S. F; SCHMIDT, A. M. Advanced glycation endproducts: from precursors to RAGE: round and round we go. Amino Acids, v. 42 , p. 1151-61, 2012

59. RAPOSEIRAS-ROUBÍN, S. et al. Soluble receptor of advanced glycation end products levels are related to ischaemic aetiology and extent of coronary disease in chronic heart failure patients, independent of advanced glycation end products levels: New Roles for Soluble RAGE. Eur J Heart Fail, v. 12, p. 1092-100, 2010.

60. RAUCCI, A. et al. A soluble form of the receptor for advanced glycation endproducts (RAGE) is produced by proteolytic cleavage of the membranebound form by the sheddase a disintegrin and metalloprotease 10 (ADAM10). FASEB J, v. 22, p. 3716-27, 2008.

61. SANTILLI, F. et al. Soluble forms of RAGE in human diseases: clinical and therapeutical implications. Curr Med Chem, v. 16, p. 940-52, 2009.

62. SCHLUETER, C. et al. Tissue-specific expression patterns of the RAGE receptor and its soluble forms--a result of regulated alternative splicing? Biochim Biophys Acta, v. 1630, p. 1-6, 2003.

63. SEMBA, R. D. et al. Elevated serum advanced glycation end products and their circulating receptors are associated with anaemia in older communitydwelling women. Age Ageing, v. 38, p. 283-9, 2009a.

64. SEMBA, R. D. et al. Advanced glycation end products and their circulating receptors and level of kidney function in older community-dwelling women. Am J Kidney Dis, v. 53, p. 51-8, 2009b.

65. SOURRIS, K. C.; FORBES, J. M. Interactions between advanced glycation end-products (AGE) and their receptors in the development and progression of diabetic nephropathy - are these receptors valid therapeutic targets. Curr Drug Targets, v. 10, p. 42-50, 2009.

66. SUGAYA, K. et al. Three genes in the human MHC class III region near the junction with the class II: gene for receptor of advanced glycosylation end products, PBX2 homeobox gene and a notch homolog, human counterpart of mouse mammary tumor gene int-3. Genomics, v. 23, p. 408-19, 1994

67. TAM, X. H. et al. Enhanced expression of receptor for advanced glycation end-products is associated with low circulating soluble isoforms of the receptor in Type 2 diabetes. Clin Sci (Lond), v. 120, p. 81-9, 2011.

68. TESAROVÁ, P. et al. Receptor for advanced glycation end products (RAGE)-soluble form (sRAGE) and gene polymorphisms in patients with breast cancer. Cancer Invest, v. 25, p. 720-5, 2007.

69. TESSIER, F.J. The Maillard reaction in the human body. The main discoveries and factors that affect glycation. Pathol Biol (Paris), v. 58, p. 214-9, 2010.

70. THOMAS, M. C. Advanced glycation end products. Contrib Nephrol, v. 170, p. 66-74, 2011

71. THORPE, S. R.; BAYNES, J. W. Maillard reaction products in tissue proteins: new products and new perspectives. Amino Acids, v. 25, p. 275-81, 2003.

72. WANG, E.; CAMBI, F. Heterogeneous nuclear ribonucleoproteins $\mathrm{H}$ and $\mathrm{F}$ regulate the proteolipid protein/DM20 ratio by recruiting U1 small nuclear ribonucleoprotein through a complex array of $\mathrm{G}$ runs.J Biol Chem, v. 284, p.11194-204, 2009 .

73. WAUTIER, J. L. et al. Receptor-mediated endothelial cell dysfunction in diabetic vasculopathy. Soluble receptor for advanced glycation end products blocks hyperpermeability in diabetic rats. J Clin Invest, v. 97, p. 238-43, 1996 74. WHITE, J. M. ADAMs: modulators of cell-cell and cell-matrix interactions Curr Opin Cell Biol, v. 15, p. 598-606, 2003.

75. WHO. World Health Organization. Diabetes Programme. Disponível em: <http://www.who.int/diabetes/en/>. Acesso em: 7 jan. 2011

76. YAMAGISHI, S. I. et al. Role of advanced glycation end products (AGEs) and oxidative stress in vascular complications in diabetes. Biochim Biophys $A c t a$, v. 1820 , p. 663-71, 2012

77. YONEKURA, H. et al. Novel splice variants of the receptor for advanced glycation end-products expressed in human vascular endothelial cells and pericytes, and their putative roles in diabetes-induced vascular injury. Biochem J, v. 370, p. 1097-109, 2003.

78. YONEKURA, H. et al. Roles of the receptor for advanced glycation endproducts in diabetes-induced vascular injury.J Pharmacol Sci, v. 97, p. 305-11, 2005.

79. ZENG, S. et al. Receptor for advanced glycation end product (RAGE)dependent modulation of early growth response-1 in hepatic ischemia/ reperfusion injury. J Hepatol, v. 50, p. 929-36, 2009 .

80. ZHANG, L. et al. Receptor for advanced glycation end products is subjected to protein ectodomain shedding by metalloproteinases. J Biol Chem, v. 283 p. 35507-16, 2008

81.ZONG, H. et al. Homodimerization is essential for the receptor for advanced glycation end products (RAGE)-mediated signal transduction. J Biol Chem v. 285 , p. $23137-46,2010$

\section{MAILING ADDRESS}

Mauren Isfer Anghebem-Oliveira

Rua Lothário Meissner, 632; Jardim Botânico; CEP: 80210-170; Curitiba-PR, Brazil; e-mail: mauren_isfer@hotmail.com. 